\title{
Serum alkaline ribonuclease derived from vascular endothelial cells is raised in patients with rheumatoid vasculitis
}

\author{
M ORIBE, M SHINGU, AND M NOBUNAGA
}

From the Department of Internal Medicine, Medical Institute of Bioregulation, Kyushu University 69, Beppu, Japan

SUMMARY We investigated the mechanisms of the marked increase of alkaline ribonuclease (RNase) in the sera of patients with rheumatoid arthritis associated with vasculitis. Among various tissues examined, blood vessels contained higher levels of alkaline RNase than acid RNase. Cultured human endothelial cells contained significantly higher amounts of alkaline RNase than acid RNase. In contrast, acid RNase was predominant in most other tissues and cells. Endothelial cells cultured with sera from patients with vasculitis released alkaline RNase into the extracellular medium. The phosphocellulose chromatographic profile of these sera differed from that of sera from healthy subjects. These results imply that the alkaline RNase in sera of patients with vasculitis is derived from blood vessels, probably from endothelial cells.

Serum ribonucleases (RNases) are raised in a number of pathological states. The pathogenesis and clinical significance of the increased levels have been difficult to assess as these enzymes are non-specific. Reddi reported similarities between human serum RNase and human pancreatic RNase and suggested that serum RNases may be of pancreatic origin. ${ }^{1}$ Recent work confirmed that antibody to pancreatic RNase inhibited nearly $100 \%$ of serum RNase activity. ${ }^{2}$ On the other hand, there are reports of a non-specific increase of the serum RNase in patients with a malignancy, ${ }^{3}$ and of serum RNase activity after pancreatectomy. ${ }^{4}$

Different classes of human serum RNases have distinctive $\mathrm{pH}$ optima, substrate specificity, and antigenic properties. These include acid RNase (Ac-R) and alkaline RNase (Al-R). Both types of these enzymes are present in varying proportions in different tissues. One type or the other predominates in most human tissues.

Akagi et al obtained evidence for five RNase components in normal human serum, ${ }^{5}$ and each of these components was separated by polyacrylamide gel electrophoresis by Blank and Dekkar. ${ }^{6}$ We now

Accepted for publication 21 April 1986

Correspondence to Dr M Shingu, Department of Internal Medicine, Medical Institute of Bioregulation, Kyushu University 69 , Tsurumihara, Beppu, Japan 874. report that Al-R is markedly increased in sera from patients with rheumatoid vasculitis.

\section{Materials and methods}

CHEMICALS

The following materials were purchased from commercial sources: yeast RNA (Sigma), phosphocellulose (Brown Co.), Sephadex G-75 (Pharmacia Fine Chemicals), RPMI 1640, fetal calf serum, Lglutamine, penicillin-streptomycin, Fungizone.

PREPARATION OF HUMAN TISSUES

AND SERUM

Sera were obtained from healthy volunteers and patients with rheumatoid arthritis (RA), with or without vasculitis. All patients with RA had definite or classical RA according to the American Rheumatism Association criteria. ${ }^{7}$ Vasculitis was demonstrated either clinically ${ }^{8}$ or histologically. In these patients there were no apparent manifestations of hepatic, renal, or pancreatic involvement. All patients with renal failure had chronic glomerulonephritis, and the blood urea nitrogen was over 60 $\mathrm{mg} / \mathrm{dl}(9.96 \mathrm{mmol} / \mathrm{l})$ or the serum creatinine levels exceeded $4.0 \mathrm{mg} / \mathrm{dl}(353.6 \mu \mathrm{mol} / \mathrm{l})$, or both. Serum was also obtained from two patients with polyarteritis nodosa. Samples of human tissues were obtained at autopsy from three patients who died of acute 
myelocytic leukaemia. None of the tissue samples obtained showed histological evidence of leukaemic cell infiltration. Immediately upon removal tissues were frozen and stored at $-80^{\circ} \mathrm{C}$. The thawed tissues were cut into small pieces, suspended in ice cold phosphate buffered saline $(0.01 \mathrm{M}, \mathrm{pH} 7.4)$, and then homogenised with a polytron PCU-2 homogeniser at a power setting of 10 for 20 seconds, interspersed with chilling on ice, followed by sonication for 45 seconds with a sonifier B-12 (Branson) at $50 \mathrm{~W}$. After centrifugation at $3500 \mathrm{rpm}$ for $10 \mathrm{~min}$ the supernatants were collected and used for RNase assay or phosphocellulose chromatography. Protein concentration of the supernatant was measured by the method of Lowry et $a l^{9}$ and the protein content expressed as milligrams wet weight. The segments of aorta were cut longitudinally and dissected into adventitia, media, and intima.

EN Z YME ASSAY

Standard assays of Ac-R and Al-R were performed by the method of Akagi et al. ${ }^{10}$ The assay of Al-R activity of each eluted fraction on phosphocellulose chromatography was slightly modified. After the reaction mixture $(1.2 \mathrm{ml})$ containing $0.175 \mathrm{M} \mathrm{NaCl}$, $1 \mathrm{ml}$ of $0.5 \%$ yeast RNA, and $0.2 \mathrm{ml}$ of sample had been incubated for two hours at $37^{\circ} \mathrm{C}$ the reaction was stopped by the addition of $0.2 \mathrm{ml}$ of $3 \%$ perchloric acid containing $0.5 \%$ uranyl acetate. The reaction was stopped by placing the tubes in ice for $10 \mathrm{~min}$. The cloudy reaction mixtures were centrifuged at $2000 \mathrm{~g}$ for $5 \mathrm{~min}, 0.8 \mathrm{ml}$ aliquots of the resulting supernatant were diluted with $2 \mathrm{ml}$ of distilled water, and the absorbance of acid soluble nucleotides was measured at $260 \mathrm{~nm}$ with a Beckman model 35 spectrometer.

PREPARATION OF HUMAN VASCULAR

ENDOTHELIAL CELLS

Vascular endothelial cells (EC) from the human umbilical cord vein were cultured by the method of Jaffe et al. ${ }^{11}$ Briefly, a vein of untraumatised umbilical cord obtained at the time of normal delivery or at caesarean section was cannulated with polyethylene tubing and perfused with cord buffer $(0.14 \mathrm{M} \mathrm{NaCl}, 0.004 \mathrm{M} \mathrm{KCl}, 0.001 \mathrm{M}$ phosphate buffer pH 7.4, 0.001 M glucose). The lumen was filled with $10-15 \mathrm{ml}$ of $0.25 \%$ trypsin (Gibco), and the preparation was incubated for $20 \mathrm{~min}$ in a $5 \%$ $\mathrm{CO}_{2}$ incubator at $37^{\circ} \mathrm{C}$. The trypsin solution containing $\mathrm{EC}$ was flushed from the vein into a $50 \mathrm{ml}$ conical tube, centrifuged at $1500 \mathrm{rpm}$, and resuspended in RPMI 1640 medium supplemented with $20 \%$ fetal calf serum, $1 \%$ antibiotics (penicillin 200 $\mathrm{U} / \mathrm{ml}$, streptomycin $200 \mathrm{ng} / \mathrm{ml}$ ), and $1 \%$ L-glutamine ( $2 \mathrm{mM})$. Approximately $2 \cdot 5 \mathrm{ml}$ of the cell suspen- sion was poured into each of two plastic $25 \mathrm{~cm}^{2}$ culture flasks (Falcon). The cells were cultured and fed every two to three days. The cultured cells were identified as EC as described previously. ${ }^{12}$ The confluent cell monolayers were trypsinised, washed, and sonicated with a sonifier B-12 for $30 \mathrm{~s}$ at $50 \mathrm{~W}$, on ice. After centrifugation at $1500 \mathrm{~g}$ for $20 \mathrm{~min}$ the supernatant was used for RNase assay. Enzyme activity was expressed as units/mg wet weight.

PHOSPHOCELLULOSE CHROMATOGRAPHY Serum was dialysed overnight in ice against 20 volumes of sodium phosphate buffer $(0.01 \mathrm{M}, \mathrm{pH}$ $6 \cdot 7)$. One millilitre of the supernatant obtained by centrifugation at $3000 \mathrm{~g}$ for $15 \mathrm{~min}$ was applied to a phosphocellulose column $(0 \cdot 8 \times 10 \mathrm{~cm})$ equilibrated with $50 \mathrm{ml}$ of buffer and $50 \mathrm{ml}$ of the same buffer containing $0.2 \mathrm{M} \mathrm{NaCl}$. One hundred and sixty millilitres ( $80 \mathrm{ml}$ each) of a linear gradient elution from $0.2 \mathrm{M}$ to $0.9 \mathrm{M} \mathrm{NaCl}$ was applied at a flow rate of $7.6 \mathrm{ml} / \mathrm{h}$ and $1.76 \mathrm{ml} /$ tube. Three normal sera and three vasculitic sera were used.

\section{ENZYME RELEASE FROM ENDOTHELIAL}

CELLS

Cultured EC were suspended in the medium a $4 \times 10^{6} / \mathrm{ml}$. The cell suspension was planted in 24-well dishes and cultured for 24 hours. Afteti exchange of medium, sera from patients with RA or control sera were added and the culture allowed to proceed for another 24 hours (A). In a separate dish an equal volume of medium plus serum was incubated in a similar manner and this served as the control (B). Dishes were centrifuged at $1000 \mathrm{rpm}$ for $10 \mathrm{~min}$, and the supernatants were used to measure RNase activity. Enzyme release was calculated by subtracting $B$ from $A$.

STATISTICAL ANALYSIS

Statistical significance was determined by Student's $t$ test.

\section{Results}

There was a marked increase in Ac-R and a decrease of the $\mathrm{Al}-\mathrm{R} / \mathrm{Ac}-\mathrm{R}$ ratio in patients with renal failure. In those with $\mathrm{RA}$ without vasculitis there was a slight increase in Al-R, while the increase in Ac- $R$ was insignificant. In those with RA and vasculitis both types of RNase were significantly increased compared with the non-vasculitic RA group and the Al-R/Ac-R ratio was significantly higher than in the normal group (Table 1). Al-R was predominant in the pancreas and blood vessels, whereas other tissues showed an Ac-R predominance. Consequently, the Al-R/Ac- $\mathrm{R}$ ratio of the aorta was significantly higher than in the liver, 
spleen, or lung (Table 2). To characterise the distribution of RNase in blood vessels, RNases were measured in each component of the aorta. While there was no significant difference of Ac-R between the intima and adventitia, Al-R of the intima was significantly higher than that of the media. Al-R was markedly higher in cultured EC than in any of these segments (Table 3). Sera from patients with

Table 1 RNase activities of the serum from patients with rheumatoid arthritis, renal failure, and from normal persons

\begin{tabular}{llll}
\hline Subjects & $\begin{array}{l}\text { Alkaline } \\
\text { RNase } \\
(\text { OD } \\
\left.10^{3} / \mathrm{mg}\right)^{\ddagger}\end{array}$ & $\begin{array}{l}\text { Acid } \\
\text { RNase } \\
(\text { OD } \\
\left.10^{3} / \mathrm{mg}\right) \ddagger\end{array}$ & $\begin{array}{l}\text { Alkalinel } \\
\text { acid } \\
\text { ratio }\end{array}$ \\
\hline $\begin{array}{l}\text { Normal persons } \\
(\mathrm{n}=16)\end{array}$ & $141(17)$ & $84(17)$ & $1 \cdot 73(0 \cdot 30)$ \\
$\begin{array}{l}\text { Renal failurc } \\
(\mathrm{n}=10)\end{array}$ & $621(119)^{*}$ & $521(116)^{* * *}$ & $1 \cdot 21(0 \cdot 15)^{* *}$ \\
$\begin{array}{l}\text { Rhcumatoid } \\
\text { arthritis without } \\
\text { vasculitis (n=20) }\end{array}$ & $157(24)$ \\
$\begin{array}{l}\text { Rhcumatoid } \\
\text { arthritis with } \\
\text { vasculitis (n=16) }\end{array}$ & $276(60)^{* * * *}$ & $139(32)^{* * * *}$ & $2 \cdot 02(0 \cdot 37)^{*}$ \\
\hline
\end{tabular}

Data are expressed as mean (SD). Statistical significance $v$ normal persons: ${ }^{*} \mathrm{p}<0 \cdot 05$; ${ }^{* *} \mathrm{p}<0 \cdot 01 ;{ }^{* * *} \mathrm{p}<0 \cdot(001$; statistical significance: $\ddagger \mathrm{p}<() \cdot(0) 1 ; \ddagger \mathrm{OD}=$ optical density. vasculitis released significantly greater amounts of Al-R from EC compared with sera from those with non-vasculitic RA (Table 4).

We attempted to study the phosphocellulose chromatographic profile of $\mathrm{Al}-\mathrm{R}$. The profile in normal human serum closely resembled the profile previously reported, ${ }^{5}$ and each of the five peaks of activity was as numbered $1-5 .{ }^{5}$ RNase 2 and 3 were relatively higher in sera from the vasculitic patients (data not shown). In general, the profile of vasculitic serum differed from that of normal human serum.

Table 4 Alkaline $\mathrm{RNase}$ and $\mathrm{LDH} \mathrm{H}^{\dagger}$ activities released by endothelial cells cultured with serum

\begin{tabular}{|c|c|c|c|}
\hline $\begin{array}{l}\text { Source of } \\
\text { serum }\end{array}$ & Number & $\begin{array}{l}\text { Alkaline } \\
\text { RNase } \\
\left(O D \times 10^{3}\right)\end{array}$ & $L D H$ (unit) \\
\hline Normal person & 11 & $21(16)$ & $1.9(3.9)$ \\
\hline $\begin{array}{l}\text { Rheumatoid arthritis } \\
\text { without vasculitis }\end{array}$ & 15 & $22(26)\rceil$ & $1 \cdot 0(2 \cdot 6)$ \\
\hline $\begin{array}{l}\text { Rheumatoid arthritis } \\
\text { with vasculitis }\end{array}$ & 10 & 69 (48) & $1 \cdot 0(2 \cdot 2)$ \\
\hline
\end{tabular}

Data are expressed as mean (SD).

Statistical significance: ${ }^{* *} \mathrm{p}<0 \cdot 01$.

$+\mathrm{LDH}=$ lactic dehydrogenase; $\mathrm{OD}=$ optical density.

Table 2 RNase activities of the tissue extracts of various human organs

\begin{tabular}{|c|c|c|c|c|}
\hline Organ & Number & $\begin{array}{l}\text { Alkaline RNase } \\
\left(O D \times 10^{3} / \mathrm{mg}\right) \dagger\end{array}$ & $\begin{array}{l}\text { Acid RNase } \\
\left(O D \times 10^{3} / \mathrm{mg}\right) \dagger\end{array}$ & $\begin{array}{l}\text { Alkalinelacid } \\
\text { ratio }\end{array}$ \\
\hline $\begin{array}{l}\text { Kidney } \\
\text { Liver } \\
\text { Spleen } \\
\text { Muscle } \\
\text { Lung } \\
\text { Pancreas } \\
\text { Aorta } \\
\text { Femoral artery }\end{array}$ & $\begin{array}{l}3 \\
3 \\
3 \\
3 \\
3 \\
2 \\
3 \\
1\end{array}$ & $\begin{aligned} & 559(138) \mathrm{NS} \\
& 49(7)^{* * *} \\
& 43(7)^{* * *} \\
& 58(18)^{* * *} \\
& 82(43)^{* * *} \\
& 302(132) \mathrm{NS} \\
& 789(158) \\
& 1169\end{aligned}$ & $\begin{array}{r}611(120) \\
108(40) \\
182(33) \\
86(19) \\
149(16) \\
224 \\
407 \\
472\end{array}\left(\begin{array}{l}74 \\
25)\end{array}\right.$ & $\begin{array}{l}0.91(0.13) \text { NS } \\
0.49(0.12)^{*} \\
0.24(0.02)^{* *} \\
0.67(0.14)^{*} \\
0.52(0.32)^{*} \\
1.30(0.23) \mathrm{NS} \\
1.96(0.55) \\
2.47\end{array}$ \\
\hline
\end{tabular}

Data are expressed as mean (SD). Statistical significance $v$ aorta: NS $=$ not significant; ${ }^{*} \mathrm{p}<0 \cdot 05 ;{ }^{* *} \mathrm{p}<0 \cdot 02 ;{ }^{* * *} \mathrm{p}<0 \cdot 01$.

†OD=optical density.

Table 3 RNase activities of vascular components and cultured endothelial cells

\begin{tabular}{|c|c|c|c|c|}
\hline Component & Number & $\begin{array}{l}\text { Alkaline RNase } \\
\left(O D \times 10^{3} / \mathrm{mg}\right)^{\dagger}\end{array}$ & $\begin{array}{l}\text { Acid RNase } \\
\left(O D \times 10^{3} / \mathrm{mg}\right) \dagger\end{array}$ & $\begin{array}{l}\text { Alkalinelacid } \\
\text { ratio }\end{array}$ \\
\hline Adventitia & 4 & $1119(270) \longrightarrow$ & 881 (117) & $1.26(0.16)$ \\
\hline Media & 4 & $1080(120)_{7}$ & 788 (117) & $1.38(0 \cdot 12) 7$ \\
\hline Intima & 3 & $\begin{array}{c}1590(110) \\
7^{*} \\
*^{*}\end{array} *^{* i}$ & $1023(170)$ & \begin{tabular}{rr|r|}
1.58 & $(0.21)$ & $*$ \\
& $*$ \\
& $*$ & $*$ \\
$*$
\end{tabular} \\
\hline Endothelial cells & 2 & $3050(920) \perp$ & $1000(424)$ & $3.14\left(0 . \frac{1}{4} 1\right) \perp$ \\
\hline
\end{tabular}

Data are expressed as mean (SD). Statistical significance: ${ }^{*} \mathrm{p}<0 \cdot 05 ;{ }^{* *} \mathrm{p}<0 \cdot 02 ;{ }^{* * *} \mathrm{p}<0 \cdot 01$. 


\section{Discussion}

RNase activities in the vascular tissues and vascular EC have received little attention. To our knowledge there are no data in the literature on the possible role of RNases in the pathogenesis of rheumatoid vasculitis or the possible origin of $A l-R$ in vasculitic serum. The results of the present study suggest that $A l-R$ is predominantly increased in sera from vasculitic patients, and the source of this Al-R is assumed to be vascular EC, the evidence being indirect. The finding that $\mathrm{Al}-\mathrm{R}$ predominates over Ac- $R$ in tissue of the pancreas is in agreement with previous findings. ${ }^{13}$

Since vascular EC are the tissues primarily affected in vasculitis the finding that vascular EC contain significant amounts of $\mathrm{Al}-\mathrm{R}$, and that EC release Al-R, is adequate to explain the mechanism by which $\mathrm{Al}-\mathrm{R}$ is increased in the serum of patients with rheumatoid vasculitis. The finding that $\mathrm{Al}-\mathrm{R}$ was raised in the serum from two patients with primary vasculitis also supports this explanation, suggesting that the increase of serum Al-R is not specific for rheumatoid vasculitis. Phosphocellulose column chromatography of serum Al-R showed that the elution profile of vasculitic serum differed from that of normal serum. The Al-R in the vasculitic serum could have been of pancreatic origin since the pancreatic tissue showed Al-R predominance. This possibility was excluded, however, since the patients with vasculitis apparently had no pancreatic lesions. It has been suggested that the pathogenetic role of neutrophils in immunologically mediated vasculitis is important. The fact that most neutrophil RNases are Ac-R,${ }^{14}$ however, strongly suggests that increased levels of $A l-R$ in vasculitic serum are not of neutrophil origin. Vasculitic serum released Al-R from EC in culture. One possible mechanism for this is that the vasculitic serum liberated the enzyme from EC by injuring the cells. The finding that lactic dehydrogenase was not detectable in the postculture medium, however, suggests that vasculitic serum did not cause lysis of EC. Lysosomes of these cells contain RNase, ${ }^{15}$ and specific release of this lysosomal RNase may occur from EC.

It was of interest that EC were shown to differ from other cell types such as Hela cells, ${ }^{15}$ neutrophils, ${ }^{14}$ or platelets, ${ }^{16}$ in which Ac-R was predominant.
Our findings suggest that analysis of serum RNases offers a tool for the diagnosis of vasculitis. Vasculitis in patients with RA can be shown by histology if the involved area is in the skin or the gut, but when histological examination is not feasible then raised levels of Al-R and an increased Al-R/Ac-R ratio in patients with no apparent manifestations of pancreatic lesions may indicate vasculitis.

\section{References}

1 Reddi K K. Nature and possible origin of human serum ribonuclease. Biochem Biophys Res Commun 1975; 67: 110-8.

2 Reddi K K, Dreiling D A. Use of human pancreatic ribonucleases in human pancreas related ribonucleases in human serum. Biochem Biophys Res Commun 1982; 104: 14-21.

3 Kottel R H, Hoch S O, Parsons R G, Hoch J A. Serum ribonuclease activity in cancer patients. $\mathrm{Br} J$ Cancer 1978; 36: 280-6.

4 Peterson L M. Serum RNase in the diagnosis of pancreatic carcinoma. Proc Natl Acad Sci USA 1979; 76: 2630-4.

5 Akagi K, Murai K, Hirao N, Yamanaka M. Purification and properties of alkaline ribonuclease from human serum. Biochim Biophys Acta 1976; 442: 368-78.

6 Blank A, Dekkar C A. Ribonuclease of human serum, urine, cerebrospinal fluid, and leukocytes. Activity staining following electrophoresis in sodium dodecyl sulphate-polyacrylamide gels. Biochemistry 1981; 20: 2261-7.

7 Ropes M W, Bennet C A, Cobbs S, Jacox R F, Jessar R A. 193 revision of diagnostic criteria for rheumatoid arthritis. But Rheum Dis 1959; 18: 49-53.

8 Toyoda K, Saito S, Naito S, et al. HLA antigens in lassical an malignant rheumatoid arthritis in Japanese populi:ion. Tissue Antigens 1977; 10: 56-9.

9 Lowry O H, Rosenbough N J, Farr A L, Randall R J. Protein measurement with folin phenol reagent. J Biol Chem 1951; 193: 265-75.

10 Akagi K, Yamanaka M, Murai K, Niho Y, Omae T. Serum acid ribonuclease in myelogenous leukemia. Cancer Res 1978; 38: 2168-73.

11 Jaffe E A, Nachman R L, Becker C G, Kinick C R. Culture of human endothelial cells derived from umbilical vein. $J$ Clin Invest 1973; 52: 2745-56.

12 Shingu M, Hashimoto Y, Jhonson A R, Hurd E R. The search for Fc receptors on human tissue and human endothelial cells in culture. Proc Soc Exp Biol Med 1981; 167: 147-55.

13 Neuwelt E A, Bogski E S, Frank J J, Procter-Appoch K, Levy $\mathrm{C} \mathrm{C}$. Possible site of origin of human plasma ribonuclease as evidenced by isolation and partial characterization of ribonucleases from several human tissues. Cancer Res 1978; 38: 88-93.

14 Akagi K, Yamanaka M, Murai K, Omae T. Purification and properties of acid ribonucleases in human serum and leukocytes. Cancer Res 1978; 38: 2163-7.

15 Saha B K, Graham M Y, Schlessinger D. Acid ribonuclease from Hela cell lysosomes. J Biol Chem 1979; 254: 5951-7. O

16 Reddi K K. Human platelet ribonuclease. Biochem Biophys N Res Commun 1977; 79: 532-8. 